\title{
Review point on neural stem cells and neurogenic areas of the central nervous system
}

\author{
Erika Toledo da Fonseca ${ }^{1^{*}}$, Ana Carolina Furlanetto Mançanares ${ }^{1}$, Carlos Eduardo Ambrósio², \\ Maria Angélica Miglino ${ }^{1}$ \\ ${ }^{1}$ Department of Surgery, School of Veterinary Medicine and Animal Science, University of São Paulo, São Paulo, Brazil; \\ *Corresponding Author: erikafonseca@usp.br \\ ${ }^{2}$ Department of Basic Sciences of the School of Animal Science and Food Engineering, University of São Paulo, São Paulo, Brazil
}

Received 22 May 2013; revised 22 June 2013; accepted 28 June 2013

Copyright (c) 2013 Erika Toledo da Fonseca et al. This is an open access article distributed under the Creative Commons Attribution License, which permits unrestricted use, distribution, and reproduction in any medium, provided the original work is properly cited.

\begin{abstract}
The potential applications of neural stem cells (NSC) in the therapy of degenerative and traumatic diseases of the central nervous system (CNS) have aroused great scientific interest. NSCs can be recovered from specific areas of the CNS from fetuses, embryos and from adult brain as well, and under appropriate culture conditions, may be induced to differentiate into the three major neural cell types, neurons, astrocytes and oligodendrocytes. The main neurogenic areas of mammals are the subventricular zone (SVZ) and the dentate gyrus (DG) of the hippocampus, yet other areas of neurogenic potential have been identified, including frontal and parietal cortices, hippocampus and lateral wall of the lateral ventricle. Neural stem cells and differentiated neural cells are usually identified by expression of specific markers, proteins that are expressed by different cell types and/or at different stages of differentiation. The main cell markers are nestin and Sox-2 for undifferentiated NSCs, beta-III tubulin (B-III tubulin) for neurons, Galactocerebroside (GaIC) for oligodendrocytes and Glial fibrillary acid protein (GFAP) for astrocytes. In general, the main neurogenic areas, the neurogenic potential of NSC and the morphological and biological characteristics of differentiated neural cells are strikingly similar among species, yet some differences have been reported. This article presents a brief review of NSCs, neurogenic areas and techniques used for their identification and characterization in humans and experimental animals.
\end{abstract}

Keywords: Neurogenesis; Neural Stem Cells;
Subventricular Zone; Hippocampus

\section{INTRODUCTION}

Stem cells are undifferentiated cells with the ability of self-renewal and generation of progenitor cells which, in turn, are capable of differentiation and generation of mature, specialized cells. Stem cells are classified according to their differentiations potentiality in: totipotent, capable of generating embryonic and extra-embryonic cells; pluripotent, able to generate specific cells of the three germinative layers; multipotent, with limited capability of originating different specialized cell types; unipotent, with restrict potential of differentiation [1].

The term neural stem cells (NSC) have been widely used to refer to cells that 1) can generate neural tissue or are derived from neural system, 2) present some selfrenewal capacity, and 3) can generate other neural cells (in addition to themselves) through asymmetric division $[1,2]$. These cells are considered multipotent, since they are capable of originating the main cellular types of their original tissue, e.g. neurons, astrocytes and oligodendrocytes [3]. Oligodendrocytes are myelin-producer cells, whose function allows the fast conduction of electric impulse along neuron axons. Astrocytes are star-shaped cells providing structural and metabolic support to neurons, which are the main players of the nervous system [4].

Upon neuronal generation, the neuroepithelium is transformed in a tissue with multiple cell layers, and the cell layer lining the ventricle (the apical layer which contains most progenitor cells) is then called ventricular zone (VZ) [5]. The subventricular zone (SVZ), derived from VZ, is a thin layer of the lateral ventricle wall. In this layer the neural progenitor cells, capable of generating new neurons and glial cells, are located [6].

The dentate gyrus (DG) of the hippocampus harbors 
NSCs is formed in the subgranular zone and that gets differentiated in neuronal and glial cells of the granular zone of DG [2]. The new neurons added to the hippocampus during adult life contribute to cognitive functions, including learning and memory [7].

The main neurogenic areas of the mammal brain have been identified, yet several studies are still being undertaken to obtain a more detailed and precise mapping the neurogenic areas of the SNC, both during embryonic and post-natal life. This article provides a brief review of the main studies designed to identify the neurogenic areas on different animal species and of the main techniques and approaches used to identify and characterize NSCs.

\section{HUMANS}

It is well established that NSCs can be extracted from fetal brain or generated from embryonic NSCs. In addition, may be also isolated from different regions of the adult brain, such as hippocampus and SVZ [8], frontal and temporal cortices, and wall of the lateral ventricles [9-12], and from non-neurogenic areas as the spinal cord [13].

The SVZ and hippocampus are the most commonly used sources of adult neural precursor cells. In contrast, fetal tissues have been largely used as sources of multipotent neural cells. NSCs of human fetuses may be isolated from embryos that have been discarded after in vitro fertilization or from aborted fetuses [14-16].

Buddensiek et al. [8], using tissue fragments removed from the hippocampus of adult humans by routine procedures for epilepsy treatment, demonstrated that the cerebrospinal fluid increases the survival rates and stimulates glial differentiation from NSCs in vitro.

Human fetuses of different ages have been used for the identification and characterization of neural precursors $[17,18]$ and the heterogeneity of their progeny [19]. These studies comprised not only the prosencephalon (subependymal area and hippocampus) but also other regions of the brain. Undifferentiated neural precursors do not express glial markers but may be induced to differentiate in neurons. Schwartz et al. [20] prefer the use of human tissue collected post-mortem since they believe it represents an abundant source of neural progenitors, reducing or eliminating the use of embryonic and fetal tissues. Usually, the cultures were derived from cortical tissue removed from premature fetuses with 23 - 25 weeks of gestational age. Previous studies demonstrated that samples collected from human brain retain cellular viability when harvested up to $36 \mathrm{~h}$ after death [21]. Nevertheless, important differences were demonstrated when comparing cultures obtained from neonates and adults. In general, cells derived from fetal tissues show higher proliferative capacity and their morphology may differ from those obtained from neonates and adults.
The incorporation of bromodeoxyuridine (BrdU), a thymidine analog, to the nascent DNA chains in dividing cells, has been largely used as indicator of cellular proliferation in situ in the CNS. This marker has also been used to determine the origin time, migration, lineage and fate of neural cells during the development of nervous system [22-24]. Buddensiek et al. and Piper et al. [8,17] used BrdU as a marker to evaluate the potential of self-renewal of cultured cells.

On the other hand, different markers have been used to identify cell types (progenitors and differentiated), lineages and stages of differentiation of cells involved in neurogenesis. The mostly used markers are listed in Table 1 and include GFAP, $\beta$-III-tubulin $[8,17,20]$, MAP2ab $[8,20]$, nestin, Sox, vimentin, NeuN [20], GalC [8,17] and $\mathrm{O} 4[17,20]$. Techniques such as RT-PCR, flow cytometry [20] and electrophysiology with intracellular $\mathrm{Ca}++$ measurement [17] have also been used to characterize cell populations obtained and cultured. Flow cytometry allows for the separation and identification of specific cell populations, according to surface markers.

\section{MICE}

Embryonic stem cells are derived from the inner embryonic cellular mass before implantation [33]. These cells are pluripotent and can potentially originate all somatic tissues [26]. The possible induction of these cells to differentiate as to generate the desired cell type with high efficiency in vitro is still a challenge [27].

Baizabal et al. [26], studying stem cells isolated from the mesencephalon of 10-day-old mouse embryos, con-

Table 1. Key markers of neural stem cells (NSC) and differentiated neural cells.

\begin{tabular}{|c|c|c|c|}
\hline Marker & Cell Type & Species & Reference \\
\hline Nestin & $\begin{array}{l}\text { Embryonic neuroepithelial cells, } \\
\text { embryonic NSCs, other multipotent } \\
\text { neural cells }\end{array}$ & $\begin{array}{l}\text { Swine } \\
\text { Mice } \\
\text { Rats }\end{array}$ & $\begin{array}{c}{[25]} \\
{[26,27]} \\
{[28]}\end{array}$ \\
\hline Sox-2 & $\begin{array}{c}\text { Embryonary and post-natal NSCs } \\
\text { Astroglia }\end{array}$ & $\begin{array}{l}\text { Mice } \\
\text { Rats }\end{array}$ & $\begin{array}{c}{[7]} \\
{[29]}\end{array}$ \\
\hline $\begin{array}{l}\text { TuJ1 (B-III } \\
\text { tubulin) }\end{array}$ & Young neurons & $\begin{array}{l}\text { Swine } \\
\text { Primates } \\
\text { Mice }\end{array}$ & $\begin{array}{c}{[25]} \\
{[30]} \\
{[7,27]}\end{array}$ \\
\hline $\begin{array}{l}\text { NeuN, } \\
\text { MAP2 }\end{array}$ & Mature neurons & $\begin{array}{c}\text { Swine } \\
\text { Primates } \\
\text { Guinea pigs } \\
\text { Mice }\end{array}$ & $\begin{array}{cc} & {[25]} \\
& {[30]} \\
& {[31]} \\
& {[7,27]}\end{array}$ \\
\hline GFAP & Astrocytes & $\begin{array}{c}\text { Swine } \\
\text { Primates } \\
\text { Guinea pigs } \\
\text { Mice }\end{array}$ & $\begin{array}{c}{[25]} \\
{[30]} \\
{[31]} \\
{[7,27]}\end{array}$ \\
\hline GalC & Oligodendrocytes & Swine & [25] \\
\hline $\mathrm{O} 1, \mathrm{O} 4$ & $\begin{array}{c}\text { Precursors and mature } \\
\text { oligodendrocytes, respectively }\end{array}$ & $\begin{array}{l}\text { Swine } \\
\text { Mice }\end{array}$ & $\begin{array}{c}{[25]} \\
{[7,27]}\end{array}$ \\
\hline
\end{tabular}


cluded that the terminal differentiation occurs during the initial formation of the stem/progenitor cells tissue specific. In vitro, the authors concluded that embryonic stem cells promptly acquire a neural fate, even under minimal conditions. In contrast, Li et al. [27] studying 4-day-old embryos, concluded that NSC differentiation in neurons requires a special protocol, by enriching the culture medium with ectodermic derivatives as a first step towards the production of neural progenitors, since the embryoid body contains a mixed of ectoderm, mesoderm and endoderm germinal layers.

In the adult mouse CNS, as has been demonstrated in other species, neurogenesis seems to occur only in two regions, the subgranular (SGZ) and subventricular zones (SVZ), whose give rise to neurons of the hippocampal DG and olfactory bulb, respectively [32].

The SVZ is the brain area containing the most abundant population of NSCs [34]. These cells are located in a discrete region on the anterior part of SVZ (SVZa) in the brain of neonates and adults. Progenitor cells derived from SVZa have been well characterized and constitute a pure population of neural progenitors, in contrast with the posterior part of SVZ (SVZp), composed almost exclusively by astrocytes. These authors demonstrated that the protein BMP4 (bone morphogenetic protein) stimulates the differentiation of neuronal progenitors of the olfactory bulb of neonate mice, in addition to commit the differentiation of NSCs in astrocytes.

Although the lateral ventricle and other areas of the ventricular ependyma adjacent to the hippocampus contain long term auto-renewing and multipotent NSCs, the dentate gyrus (DG) of the adult does not contain a resident population of NSCs. Neural and glial progenitors with limited self-renewing capacity have been isolated from DG, suggesting that specific neural progenitors rather than multipotent stem cells constitute the source of new neurons generated in this site during adulthood [35].

In addition to SVZ and SGZ, Jiao and Chen [32] suggest that neurogenesis may be induced both in vivo and in vitro by signals triggered by trauma, or by specific pathways, suggesting that the neurogenic potential areas of the CNS may be determined by the local environment. In this study, the cultured cells derived from the gray matter of cerebral cortex, cerebellum and spinal cord along with astrocytes from adult SGZ and SVZ. The authors concluded that astrocytes secrete chemical signs which stimulate adult neural progenitors, from other brain areas, to differentiate in neurons in vitro and in vivo. According to Alvarez-Buylla and García-Verdugo [36], mouse astrocytes derived from the cerebral cortex, cerebellum and spinal cord behave as stem cells in vitro only if obtained before day 10 of age.

Both in embryo and adult mice studies, antibodies against B-III tubulin, nestin and GFAP are the most used for identification of cell types [26,27,32,35]. In addition, NeuN [26,27], O4 [26,27,32,35] and MAP2 [32,34,35] have also been used for identification and characterization of cultured neural cells. RT-PCR [27,35] and electrophysiology $[27,34]$ are other techniques used for neural cell identification.

\section{RATS}

Several aspects of the identity, dynamics and biology of neural precursors have been studied in rat embryos or adults, and the main findings seem to apply to the standard observed in other mammals.

Smith et al. [37] investigated whether embryonic rat and mouse NSCs would present species-specific or region-specific characteristics and properties upon different culture systems and inducers in vitro. It was shown that embryonic neural progenitors cultivated in serumfree medium supplemented with basic fibroblast growth factor (bEGF) present a similar pattern of proliferation, with a rather constant proliferation rate up to 4 - 5 weeks, followed by a decrease in proliferation. It was suggested that the senescence of precursor and differentiated cells, displayed after a number of passages, may be derived from their biology itself and seems to be similar in different systems, yet may be also derived from peculiarities in the culture medium, including differences in the growth factors used.

Johansson et al. [11] initially demonstrated that ependymal cells of the adult rat brain represent true NSCs. In vivo, these cells migrate throughout the SVZ and eventually reach the olfactory bulb, where they differentiate into neurons and express B-III tubulin and Map2. In vitro, these cells are capable of generating neurospheres that, under appropriate stimuli differentiate into neurons, oligodendrocytes and astrocytes. Komitova and Eriksson [29] studied the expression of Sox-2, a transcriptional factor known to be expressed in multipotent cells of the embryonic neuroepithelium, in neural progenitor cells from the SVZ of the brain of adult rats (4 months of age). Sox-2 positive cells were also identified among astroglial cells, distributed within the cerebral parenchyma. Sox-2 expression by astroglia of adult brains reinforces the neurogenic potential of these cells hypothesized by some authors. The authors conclude that Sox-2, along with other markers, may be useful to study the dynamics of neural progenitors, inclusive in adult brains.

The protein nestin is a component of intermediate filaments of the cytoskeleton, whose expression has been considered a marker of NSCs or neural progenitors. Although originally associated with embryonic or fetal stages of nervous system development, nestin expression has also been demonstrated in rat adult brain. In rats, nestin expression was demonstrated in germinal cells of neurogenic areas, including microglia cells. The biologi- 
cal significance of these findings is uncertain. In vitro, it has been demonstrated that microglia cells isolated from the brain of rat neonates [28] and from injured rat brain [38] can be induced to differentiate in neuron-like or glial-like cells, yet this potential may not be necessarily manifested in vivo. The function of nestin in these neurons may be related to cells survival and plasticity.

The effects of different chemical treatments of the culture surfaces on the behavior and differentiation of neural precursors was also studied with rat NSCs [39]. These chemical groups may influence adhesion, migration and differentiation potential and, as such, should be necessarily considered upon defining the experimental design. Surfaces treated with $-\mathrm{SO}_{3}$ favor differentiation of neurospheres in oligodendrocytes, whereas treatment with $-\mathrm{COOH},-\mathrm{NH}_{2}$, $-\mathrm{SH}$ e $-\mathrm{CH}_{3}$ favors differentiation in neurons, oligodendrocytes and astrocytes.

\section{OTHER SPECIES}

Based on the significant pre-natal development of the brain, more similar to human brain development than other rodents, guinea pigs (Cavia porcellus) have been used in research addressing post-natal neurogenesis in the hippocampal DG [31,40]. Using neuronal markers (NeuN, B-III tubulin) and glial markers (GFAP), in addition to cell proliferation (BrdU), the authors demonstrated a significant cell proliferation in the 20 first days of life, after which the proliferation decreases.

Altman and Das [40], comparing the hippocampus and the cerebellar cortex, concluded that neurogenesis is well pronounced in the hippocampus for a certain time after birth whereas cerebellar neurogenesis is minimal. The cerebellar cortex of guinea pigs is mature at birth and only a small proportion of granular cells is produced after birth. The duration of cerebellar neurogenesis in different mammals seems to correlate with the time lapse needed for maturation of the locomotor system and related abilities, in addition to differences of complexity among species. Thus, the end of cerebellar neurogenesis soon after birth in guinea pigs may be related to the limited locomotor ability that these animals have yet to develop at young age.

Adult non-human primates have also been subject of research concerning NSCs and neurogenic regions [30]. A search for neurogenic areas in the CNS of primates revealed the presence of dividing cells in the subependimal region of the lateral ventricles. These cells generate neuroblasts which undergo a massive migration through a long distance up to the olfactory bulb, where they differentiate in interneurons. Markers such as BrdU, GFAP, NeuN and B-III tubulin were used in these studies.

Pigs have been also utilized in NSC studies. Neural stem/progenitor cells were identified in the subventricular zone of lateral ventricles in 40-day fetuses [41] and newborn piglets [25]. These cells are multipotent and have the potential of generating neurons and glial cells. The differentiation capability was demonstrated by immunocytochemistry using markers as nestin (undifferentiated neural progenitors), GFAP (astrocytes), vimentin, O4 (immature oligodendrocytes), O1 (oligodendrocytes precursor cells), MAP2 (microtubule protein), NeuN (neuronal specific marker). BrdU was used to investigate cell proliferation in vitro and in vivo. RT-PCR was used to investigate gene expression.

\section{CONCLUSION}

The recent developments on stem cell research have opened new perspectives for their potential use in treatment of several human diseases. In particular, therapeutic use of neural stem cells has long been awaited and may give new hope for treatment of degenerative or traumatic neural disorders. In this sense, the use of animal models has been of great value for basic research and, as such, may be eventually useful to test therapeutic applications as well.

\section{REFERENCES}

[1] Chou Gage, F.H. (2000) Mammalian neural stem cells. Science, 287, 1433-1438. doi:10.1126/science.287.5457.1433

[2] Taupin, P. and Gage, F.H. (2002) Adult neurogenesis and neural stem cells of the central nervous system in mammals. Journal of Neuroscience Research, 69, 745-749. doi:10.1002/jnr.10378

[3] Jandial, R., Singec, I., Duenas, V.J., Ho, A.L., Levy, M.L. and Snyder, E.Y. (2007) Central nervous system repair and stem cells. International Congress Series, 1302, 154163. doi:10.1016/j.ics.2007.02.062

[4] Doetsch, F. (2003) The glial identity of neural stem cells. Nature Neuroscience, 6, 1127-1134. doi:10.1038/nn1144

[5] Gotz, M. and Huttner, W.B. (2005) The cell biology of neurogenesis. Nature Reviews Molecular Cell Biology, 6, 777-788. doi:10.1038/nrm1739

[6] Alvarez-Buylla, A. and Lois, C. (1995) Neuronal stem cells in the brain of adult vertebrates. Stem Cells, 13, 263-272. doi:10.1002/stem.5530130307

[7] Bonaguidi, M.A., Peng, C.Y., McGuire, T., Falciglia, G., Gobeske, K.T., Czeisler, C. and Kessler, J.A. (2008) Noggin expands neural stem cells in the adult hippocampus. The Journal of Neuroscience, 28, 9194-9204. doi:10.1523/JNEUROSCI.3314-07.2008

[8] Buddensiek, J., Dressel, A., Kowalski, M., Runge, U., Schroeder, H., Hermann, A., Kirsch, M., Storch, A. and Sabolek, M. (2010) Cerebrospinal fluid promotes survival and astroglial differentiation of adult human neural progenitor cells but inhibits proliferation and neuronal differentiation. BMC Neuroscience, 11, 48.

doi:10.1186/1471-2202-11-48 
[9] Arsenijevic, Y., Villemure, J.G., Brunet, J.F., Bloch, J.J., Deglon, N., Kostic, C., Zurn, A. and Aebischer, P. (2001) Isolation of multipotent neural precursors residing in the cortex of the adult human brain. Experimental Neurology, 170, 48-62. doi:10.1006/exnr.2001.7691

[10] Frisen, J., Johansson, C.B., Lothian, C. and Lendahl, U. (1998) Central nervous system stem cells in the embryo and adult. Cellular and Molecular Life Sciences, 54, 935945. doi:10.1007/s000180050224

[11] Johansson, C.B., Momma, S., Clarke, D.L., Risling, M., Lendahl, U. and Frisen, J. (1999) Identification of a neural stem cell in the adult mammalian central nervous system. Cell, 96, 25-34. doi:10.1016/S0092-8674(00)80956-3

[12] Johansson, C.B., Svensson, M., Wallstedt, L., Janson, A.M. and Frisen, J. (1999) Neural stem cells in the adult human brain. Experimental Cell Research, 253, 733-736. doi:10.1006/excr.1999.4678

[13] Mansergh, F.C., Wride, M.A. and Rancourt, D.E. (2003) Neurons stem cells and potential therapies. In: Sell, S., Ed., Stem Cells Handbook. Humana Press, New Jersey, 177-190. doi:10.1385/1-59259-411-5:177

[14] Shamblott, M.J., Axelman, J., Wang, S., Bugg, E.M., Littlefield, J.W., Donovan, P.J., Blumenthal, P.D., Huggins, G.R. and Gearhart, J.D. (1998) Derivation of pluripotent stem cells from cultured human primordial germ cells. Proceedings of the National Academy of Sciences, 95, 13726-13731. doi:10.1073/pnas.95.23.13726

[15] Thomson, J.A., Itskovitz-Eldor, J., Shapiro, S.S., Waknitz, M.A., Swiergiel, J.J., Marshall, V.S. and Jones, J.M. (1998) Embryonic stem cell lines derived from human blastocysts. Science, 282, 1145-1147. doi:10.1126/science.282.5391.1145

[16] Vescovi, A.L., Parati, E.A., Gritti, A., Poulin, P., Ferrario, M., Wanke, E., Frolichsthal-Schoeller, P., Cova, L., Arcellana-Panlilio, M., Colombo, A. and Galli, R. (1999) Isolation and cloning of multipotential stem cells from the embryonic human CNS and establishment of transplantable human neural stem cell lines by epigenetic stimulation. Experimental Neurology, 156, 71-83. doi:10.1006/exnr.1998.6998

[17] Piper, D.R., Mujtaba, T., Keyoung, H., Roy, N.S., Goldman, S.A., Rao, M.S. and Lucero, M.T. (2001) Identification and characterization of neuronal precursors and their progeny from human fetal tissue. Journal of Neuroscience Research, 66, 356-368. doi:10.1002/jnr.1228

[18] Uchida, N., Buck, D.W., He, D., Reitsma, M.J., Masek, M., Phan, T.V., Tsukamoto, A.S., Gage, F.H. and Weissman, I.L. (2000) Direct isolation of human central nervous system stem cells. Proceedings of the National Academy of Sciences, 97, 14720-14725. doi:10.1073/pnas.97.26.14720

[19] Suslov, O.N., Kukekov, V.G., Ignatova, T.N. and Steindler, D.A. (2002) Neural stem cell heterogeneity demonstrated by molecular phenotyping of clonal neurospheres. Proceedings of the National Academy of Sciences of the United States of America, 99, 14506-14511. doi:10.1073/pnas.212525299

[20] Schwartz, P.H., Bryant, P.J., Fuja, T.J., Su, H., O’Dowd,
D.K. and Klassen, H. (2003) Isolation and characterization of neural progenitor cells from post-mortem human cortex. Journal of Neuroscience Research, 74, 838-851. doi:10.1002/jnr.10854

[21] Palmer, T.D., Schwartz, P.H., Taupin, P., Kaspar, B., Stein, S.A. and Gage, F.H. (2001) Cell culture: Progenitor cells from human brain after death. Nature, 411, 42-43. doi:10.1038/35075141

[22] Altman, J. and Bayer, S.A. (1990) Mosaic organization of the hippocampal neuroepithelium and the multiple germinal sources of dentate granule cells. The Journal of Comparative Neurology, 301, 325-342. doi:10.1002/cne.903010302

[23] Crespo, D., Stanfield, B.B. and Cowan, W.M. (1986) Evidence that late-generated granule cells do not simply replace earlier formed neurons in the rat dentate gyrus. Experimental Brain Research, 62, 541-548. doi:10.1007/BF00236032

[24] Schlessinger, A.R., Cowan, W.M. and Gottlieb, D.I. (1975) An autoradiographic study of the time of origin and the pattern of granule cell migration in the dentate gyrus of the rat. The Journal of Comparative Neurology, 159, 149175. doi:10.1002/cne.901590202

[25] Ara, J., Fekete, S., Zhu, A. and Frank, M. (2010) Characterization of neural stem/progenitor cells expressing VEGF and its receptors in the subventricular zone of newborn piglet brain. Neurochemical Research, 35, 14551470. doi:10.1007/s11064-010-0207-2

[26] Baizabal, J.M. and Covarrubias, L. (2009) The embryonic midbrain directs neuronal specification of embryonic stem cells at early stages of differentiation. Developmental Biology, 325, 49-59. doi:10.1016/j.ydbio.2008.09.024

[27] Li, H.W., Liu, H., Corrales, C.E., Risner, J.R., Forrester, J., Holt, J.R., Heller, S. and Edge, A.S.B. (2009) Differentiation of neurons from neural precursors generated in floating spheres from embryonic stem cells. BMC Neuroscience, 10, 122. doi:10.1186/1471-2202-10-122

[28] Yokoyama, A., Yang, L., Itoh, S., Mori, K. and Tanaka, J. (2004) Microglia, a potential source of neurons, astrocytes, and oligodendrocytes. Glia, 45, 96-104. doi:10.1002/glia.10306

[29] Komitova, M. and Eriksson, P.S. (2004) Sox-2 is expressed by neural progenitors and astroglia in the adult rat brain. Neuroscience Letters, 369, 24-27. doi:10.1016/j.neulet.2004.07.035

[30] Kornack, D.R. and Rakic, P. (2001) The generation, migration, and differentiation of olfactory neurons in the adult primate brain. Proceedings of the National Academy of Sciences, 98, 4752-4757. doi:10.1073/pnas.081074998

[31] Guidi, S., Ciani, E., Severi, S., Contestabile, A. and Bartesaghi, R. (2005) Postnatal neurogenesis in the dentate gyrus of the guinea pig. Hippocampus, 15, 285-301. doi:10.1002/hipo.20050

[32] Jiao, J. and Chen, D.F. (2008) Induction of neurogenesis in nonconventional neurogenic regions of the adult central nervous system by niche astrocyte-produced signals. Stem Cells, 26, 1221-1230. doi:10.1634/stemcells.2007-0513

[33] Conti, L., Reitano, E. and Cattaneo, E. (2006) Neural 
stem cell systems: Diversities and properties after transplantation in animal models of diseases. Brain Pathology, 16, 143-154. doi:10.1111/j.1750-3639.2006.00009.X

[34] Liu, S.Y., Zhang, Z.Y., Song, Y.C., Qiu, K.J., Zhang, K.C., An, N., Zhou, Z., Cal, W.Q. and Yang, H. (2004) SVZa neural stem cells differentiate into distinct lineages in response to BMP4. Experimental Neurology, 190, 109-121. doi:10.1016/j.expneurol.2004.07.015

[35] Seaberg, R.M. and van der Kooy, D. (2002) Adult rodent neurogenic regions: The ventricular subependyma contains neural stem cells, but the dentate gyrus contains restricted progenitors. The Journal of Neuroscience, 22, 1784-1793.

[36] Alvarez-Buylla, A. and Garcia-Verdugo, J.M. (2002) Neurogenesis in adult subventricular zone. The Journal of neuroscience, 22, 629-634.

[37] Smith, R., Bagga, V. and Fricker-Gates, R.A. (2003) Embryonic neural progenitor cells: the effects of species, region, and culture conditions on long-term proliferation and neuronal differentiation. Journal of Hematotherapy
\& Stem Cell Research, 12, 713-725. doi:10.1089/15258160360732731

[38] Yokoyama, A., Sakamoto, A., Kameda, K., Imai, Y. and Tanaka, J. (2006) NG2 proteoglycan-expressing microglia as multipotent neural progenitors in normal and pathologic brains. Glia, 53, 754-768. doi:10.1002/glia.20332

[39] Ren, Y.J., Zhang, H., Huang, H., Wang, X.M., Zhou, Z.Y., Cui, F.Z. and An, Y.H. (2009) In vitro behavior of neural stem cells in response to different chemical functional groups. Biomaterials, 30, 1036-1044. doi:10.1016/j.biomaterials.2008.10.028

[40] Altman, J. and Das, G.D. (1967) Postnatal neurogenesis in the guinea-pig. Nature, 214, 1098-1101. doi:10.1038/2141098a0

[41] Skalnikova, H., Vodicka, P., Pelech, S., Motlik, J., Gadher, S.J. and Kovarova, H. (2008) Protein signaling pathways in differentiation of neural stem cells. Proteomics, 8, 4547-4559. doi:10.1002/pmic.200800096 